\title{
A EXPERIÊNCIA PAULISTANA EM PARQUES LINEARES
}

\section{THE SÃO PAULO LINEAR PARKS EXPERIENCE}

\author{
Wellington Tohoru Nagano \\ Fábio Mariz Gonçalves
}

RESUMO

Em 2002, o Plano Diretor Estratégico da cidade de São Paulo instituiu o Programa de Recuperação dos Fundos de Vale com o objetivo de transformar os rios em eixos de estruturação urbana, paisagística e ambiental por meio de ações de saneamento, recuperação hídrica e implantação dos parques lineares. Os parques lineares foram implantados entre 2008 e 2015, sendo incorporados ao cotidiano da população. Entretanto, diversos deles enfrentam problemas de vandalismo, falta de apropriação, sujeira e abandono, resultado de falhas nos processos de planejamento, projeto, obra e gestão. A análise será concentrada em três parques lineares implantados em zonas distintas de São Paulo: Canivete, Guaratiba e Itaim Paulista, pois tiveram formas de implantação distintas entre si, resultando em diferentes formas de apropriação. Esses parques lineares mostram que a apropriação está relacionada diretamente aos processos de planejamento, projeto e gestão, em que o Estado deve atuar no espaço público de acordo com as peculiaridades locais.

Palavras-chave: Parque Linear, Espaço Livre, Espaço Público.

\section{ABSTRACT}

In 2002, the São Paulo Strategic Masterplan created the River Valley Recovery Program, with purpose to transform the rivers into axis of urban, landscape and environmental requalification, through the sanitation, river denaturalization and implementation of linear parks. The linear parks opened between 2008 and 2015, being incorporated into daily life of the inhabitants. However, several of them have problems with vandalism, lack of appropriation, trash and abandonment, because of failure in planning, design, construction and management process. The analysis will focus in three linear parks opened in different areas of São Paulo: Canivete, Guaratiba and Itaim, since they had different forms of implementation between them, resulting in different forms of appropriation. These linear parks show that appropriation is related directly with the planning, design and management process, in which the State must act in public space according to local peculiarities.

Keywords: Linear Park, Open Space, Public Space. 


\section{INTRODUÇÃO}

Parque linear é um tipo de espaço público junto a eixos, como rios, elevados, adutoras ou canteiros centrais. Em diversas cidades, parques lineares são associados com cursos d'água.

O primeiro parque sob os atributos de linearidade junto ao rio foi criado por Frederick Law Olmsted como parte do Sistema de Parques de Boston, comumente conhecido como Emerald Necklace (Fig. 1). Olmsted não denominou como parques lineares (linear parks) as vias que interligavam as "joias" do Sistema de Parques: Boston Common e Franklin Park, mas como vias-parque, ou parkways (PANZINI, 2013). Apesar disso, é atribuída a Olmsted a criação do primeiro parque linear, entendido como parque em que a contemplação junto à natureza ocorre no movimento do usuário. A estratégia de criar espaço público junto ao rio foi realizada pouco antes de Olmsted por Peter Joseph Lenné no Plano para o Rio Spree, em Berlim (FRIEDRICH, 2007). Passado mais de um século e meio depois de suas concepções, esses espaços públicos junto aos rios tornaram-se referências paisagísticas para essas cidades

Não apenas parques junto aos rios são considerados lineares; outras situações são denominadas parques lineares: ao longo de um canteiro central (Parc Linéaire Desaulniers - Longueuil, Canadá), nos baixios de um viaduto (Underline, Miami, EUA), elevado (Promenade Planteé, Paris, França) ou sobre adutoras (Parque Linear da Integração - Zilda Arns, São Paulo, Brasil). São considerados lineares por sua conformação geométrica, ao longo de uma linha, onde as bordas são mais extensas que um parque tradicional, mesmo que ambos tenham a mesma área.

Parque linear junto ao rio tem função de aproximar as duas margens, como descrito por Lynch (1981). O rio é naturalmente uma barreira urbana e o planejamento de parque linear deve reconhecer essa condição e procurar formas de aproximação.

Geralmente, parques tradicionais são unidades autônomas, cercados, facilitando a gestão e o controle de acesso de usuários. O mesmo não ocorre com o parque linear (Fig. 2), pois em seu desenho não há fechamentos, portanto não existe controle de acesso. A dinâmica urbana é muito mais próxima de praças que de parques tradicionais, que são espaços públicos para atividades programáticas e de contemplação, enquanto que o parque linear tem ações do cotidiano, o confronto e as negociações no espaço público. E isto significa forma diferente de gestão, pois o contato do parque com a população é maior, são áreas visadas por outras secretarias para a realização de eventos ou de serviços públicos. Exemplo comum em parques lineares é a questão da limpeza. Enquanto a Secretaria Municipal do Verde e Meio Ambiente (SVMA) é responsável pela manutenção das calçadas e áreas permeáveis, a limpeza do córrego é atribuição da Subprefeitura e a conservação do meio-fio é responsabilidade da Autoridade Municipal de Limpeza Urbana (AMLURB).

\section{A Ocupação dos Fundos de Vale eM São paulo}

Ao longo do século $\mathrm{XX}$, os rios paulistanos passaram por diferentes estratégias de intervenção. Os meandros do Tietê, Tamanduateí e Pinheiros foram retificados como forma da água circular mais rapidamente e, assim, evitar doenças atribuídas ao antigo desenho do rio. O Rio Anhangabaú foi tamponado para a passagem de avenidas e depois virou parque, e muitos rios foram transformados em avenidas de fundo de vale, como os rios Saracura (Av. Nove de Julho), Itororó (Av. Vinte e Três de Maio - Fig. 3), Tatuapé (Av. Salim Farah Maluf). É o período de aspecto utilitarista dos rios (FRIEDRICH, 2007), em que os cursos d'água eram suportes para a infraestrutura (esgoto, drenagem, ferrovias e ruas) da rápida urbanização brasileira e da crescente indústria automotiva.

Posteriormente, os rios passaram a ser empecilhos para o bom funcionamento das cidades (FRIEDRICH, 2007), pois eram vistos como locais de enchentes, congestionamentos e incômodos, como mau cheiro e presença de insetos, causados pelas margens impermeabilizadas e pelo adensamento sobre as várzeas. Podemos dizer que a terceira etapa, a atual, visa recuperar ambiental- 


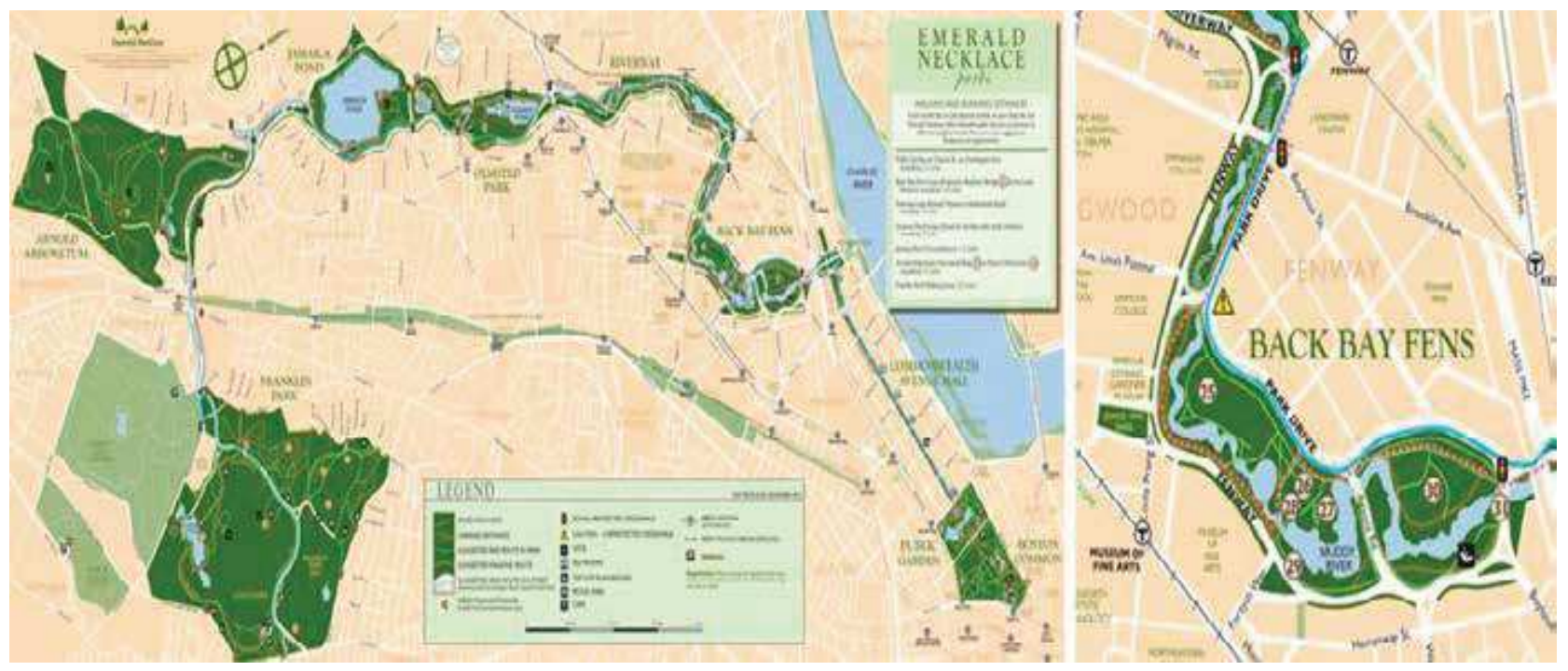

Figura 1 - Emerald Necklace, Boston - EUA.

Fonte: The Emerald Necklace Conservancy.
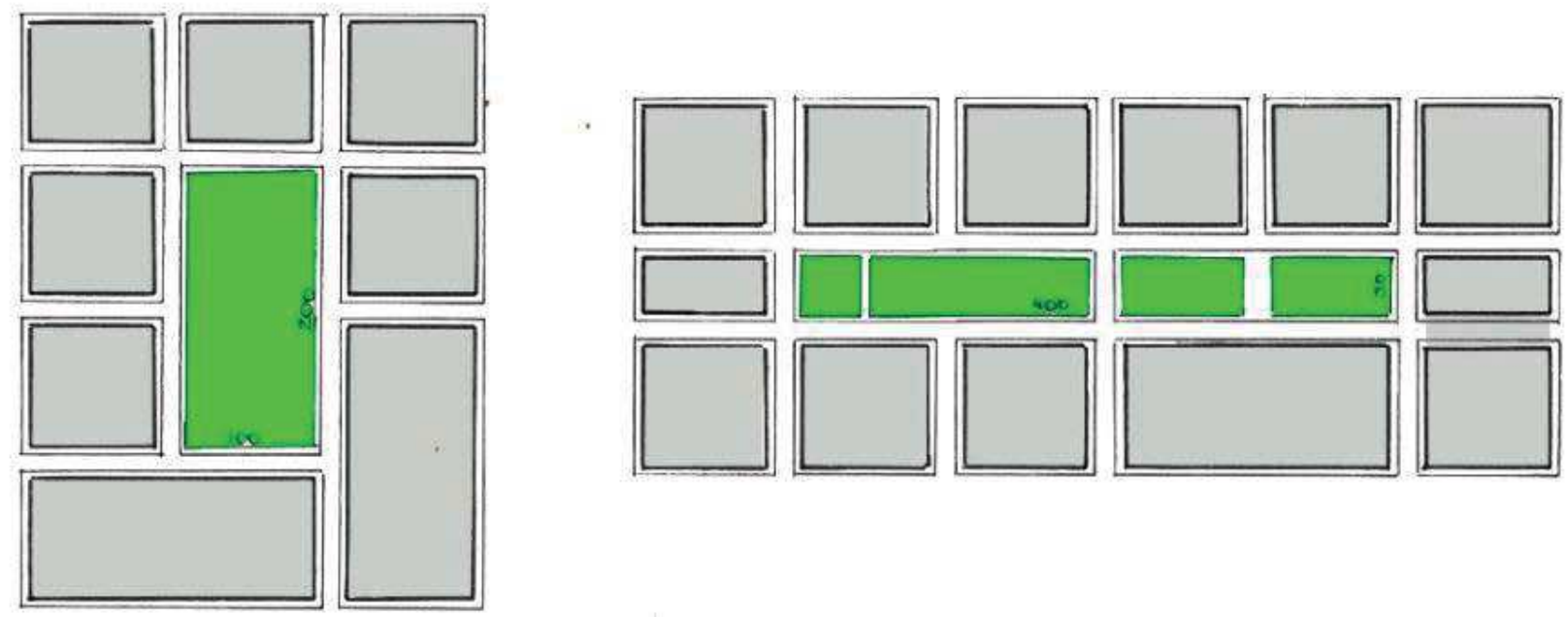

Figura 2 - Comparação entre parque tradicional (à esq.) com o parque linear (à dir.). Ambos possuem a mesma área (20.000

$\left.\mathrm{m}^{2}\right)$, entretanto o perímetro do parque linear $(900 \mathrm{~m})$ é $50 \%$ maior que o do parque tradicional $(600 \mathrm{~m})$.
Desenho: Wellington Tohoru Nagano. 
mente os córregos e integrá-los - do ponto de vista econômico, social e ambiental - com as dinâmicas urbanas.

Em áreas periféricas, os rios não tiveram as mesmas intervenções, nem o mesmo interesse do poder público quanto às áreas centrais. Sem atratividade comercial, os loteadores evitavam a ocupação dessas áreas nos projetos de loteamento. Para atende a lei 6.776/1979, conhecida como Lei do Parcelamento do Solo, os loteadores colocavam as áreas públicas destinadas ao verde e institucional junto aos rios e morros - locais de baixo interesse comercial - de forma a vender mais lotes nas áreas consideradas nobres do loteamento. Diante dessa prática, a lei 7.803/1989 impôs nas areas urbanas os mesmos padrões de preservação dos cursos d'água constante na lei 4.771/1965, conhecida como Códi- go Florestal, até então restrita às áreas rurais (QUEIROGA, 2012). A lei determinou que rios e morros sejam Áreas de Preservação Permanente (APP), na quais foi estabelecida a preservação de um mínimo de 30 metros para cada margem. A aplicação dessas leis no meio urbano, em locais já estabelecidos, não ocorreu na prática, pois a intensa urbanização não deixou áreas suficientes para a preservação conforme as leis. Entretanto, para os novos loteamentos, a lei 7.803/1989 acabou gradualmente com a prática dos loteadores urbanos de deixar junto às margens áreas verdes e institucionais (QUEIROGA, 2012).

Como o Código Florestal não determinava como deveria ser a ocupação e a gestão das Áreas de Proteção Permanente, foi publicada em 2006 a Resolução 369 do Conselho Nacional do Meio

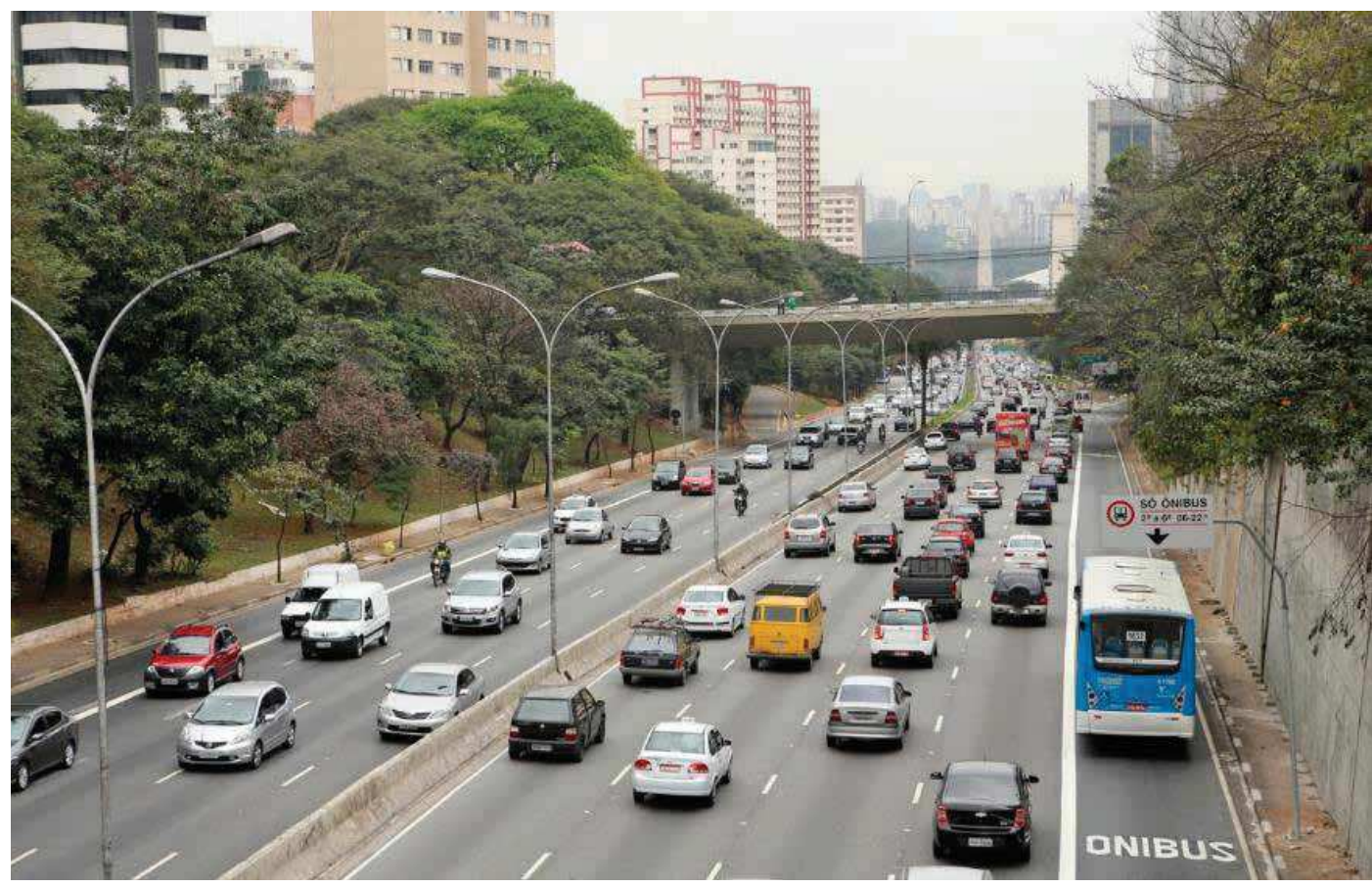

Figura 3 - Avenida 23 de Maio.

Foto: Fábio Arantes, Prefeitura de São Paulo. 
Ambiente (CONAMA), estabelecendo os procedimentos de intervenções e a regularização nas APPs, com o objetivo de restaurar ambientalmente os rios. As intervenções sobre as APPs destinamse à implantação de obras, atividades, plano e ações de utilidade pública ou de baixo impacto ambiental (BRASIL, 2006).

A ocupação das APPs sob essa resolução deve ser destinada exclusivamente ao Poder Público, para a instalação de equipamentos ou para a ampliação de áreas verdes. Em contrapartida, o interventor deverá fazer melhorias dentro da mesma bacia hidrográfica onde situa o curso d'água. A Resolução CONAMA 369 prevê também a regularização fundiária junto aos rios, desde que a área esteja classificada como Zona Especial de Interesse Socia (ZEIS) e que atenda no mínimo três itens de infraestrutura: malha viária, acesso à rede de água, captação de águas pluviais, rede de esgoto, coleta de lixo, rede de energia e densidade populacional de 50 habitantes por hectare (BRASIL, 2006).

Da mesma forma que a Resolução CONAMA 369 estabelece procedimentos de intervenção em áreas de proteção ambiental, ela pode ter interpretações ambíguas. Uma avenida, por exemplo, pode ser implantada em fundo de vale desde que seja enquadrada como interesse social ou que haja uma creche construída próxima de um córrego. Da mesma forma que a Resolução CO NAMA 369 permite critérios e ordenamento de ocupações nas APPs, ela também pode ser utilizada pelo Poder Público como chancela para construir em áreas ambientais, sobre o pretexto de interesse social.

\section{Histórico dos Parques Lineares em São paulo}

A primeira vez que os parques lineares apareceram oficialmente no planejamento urbano de São Paulo foi na Lei 13.430/2002, que instituía o Plano Diretor Estratégico (PDE) da cidade, através do Artigo 57. Os parques lineares, sob o PDE, eram destinados aos equipamentos comunitários de lazer, ampliação de áreas verdes, reurbanização de favelas, ciclovias, drenagem, saneamento, locais para educação ambiental, além de uma forma de evitar ocupações ilegais.
Os parques lineares estavam inseridos no Programa de Recuperação Ambiental de Cursos D'Água e Fundos de Vale, previsto no Artigo 106. A prioridade de implantação dos parques lineares deveria ser no sentido da nascente para a jusante dos rios (SÃO PAULO, 2002). Como forma de desestimular a ocupação em locais previstos para os parques lineares, os proprietários poderiam transferir o potencial construtivo dos imóveis junto aos rios para outra área distante até 200 metros do parque. Esse incentivo deveria ter lei específica para tal, o que acabou não se efetivando. Foram previstos 37 parques lineares pelo PDE 2002, sendo 15 entregues até 2006 e o restante até 2012.

As primeiras ações municipais ocorreram por volta de 2006 , quando a SVMA escolheu 33 regiões prioritárias para a implantação dos parques lineares (Tab. 1), que foram transformados no Programa de Parques Lineares, lançado no mesmo ano. As áreas escolhidas para os futuros parques lineares não coincidiam com os previstos do PDE 2002

Foram priorizadas as principais bacias contribuintes dos rios Pinheiros e Tietê, as que abastecem o sistema GuarapirangaBillings e, por último, as localizadas junto à base da Serra da Cantareira. As bacias dos rios Aricanduva, Cabuçu de Cima, Morro do $S$ e Pirajussara foram escolhidas, enquanto que na região das represas foram selecionadas as bacias do Caulim e Cocaia (DEVECCHI, IKEDA, ALEX, 2009)

Algumas bacias selecionadas são de grandes dimensões e em áreas altamente urbanizadas, demandando maiores recursos (financeiro e técnico) para a desapropriação e a implantação dos parques. Diante disso, foi priorizado o estabelecimento de um banco de terras públicas (DEVECCHI, IKEDA, ALEX, 2009) para garantir a implantação de parques. Os recursos para a compra de terras em áreas prioritárias eram provenientes da própria dotação orçamentária da SVMA, do Fundo de Desenvolvimento Urbano (FUNDURB), do Fundo Especial do Meio Ambiente (FEMA) e de fontes externas, como os Termos de Compensação Ambiental (TCA) por grandes empreendimentos, como o Rodoanel Sul. 
Apesar de existirem vários fundos municipais para a implantação dos parques lineares, eles não cobriam todos os planejados. Em levantamento realizado na SVMA, apenas a desapropriação de todos os núcleos do Parque Linear Cocaia, na Subprefeitura da Capela do Socorro, seria superior a R\$120 milhões, ou $68 \%$ do orçamento previsto para a SVMA para 2016 (R\$ 169 milhões).

Como forma de preservar os terrenos dos futuros parques lineares sem utilizar as receitas orçamentárias e evitar perdas para o mercado imobiliário, foram criados inúmeros Decretos de Utilidade Pública (DUP), garantindo que a municipalidade tenha prioridade na compra do lote durante cinco anos e, caso nesse período não haja desapropriação ou renovação do decreto, este perderá a vigência e o município só poderá decretar outro DUP um ano depois.

Esse período, entre 2006 e 2008, foi a primeira fase dos parques lineares em São Paulo, com a SVMA responsável pela escolha de áreas, aquisição de terrenos, publicação das DUPs e a criação legal dos parques, através de decretos. Simultaneamente, surgiram iniciativas de algumas subprefeituras e de outras secretarias municipais para a criação de parques lineares. Com dimensões menores e atendendo objetivos específicos, foi o segundo período de planejamento dos parques lineares.

Em 2008, foi lançado o Programa 100 Parques, com a meta de alcançar 100 parques (entre naturais, urbanos e lineares) administrados pela SVMA até o final de 2012, número superior aos 35 existentes em 2005. Por ser um plano mais abrangente, o Programa 100 Parques incorporou o Programa de Parques Lineares.

Além das fontes de recursos tradicionais (SVMA, FEMA, FUNDURB e TCA), foram utilizadas verbas de outras secretarias, como a da Habitação (SEHAB), Subprefeituras e de Infraestrutura Urbana e Obras (SIURB), além de órgãos estaduais, como a Companhia de Saneamento Básico de São Paulo (SABESP) e o Fundo Estadual de Recursos Hídricos (FEHIDRO).

Projetar parques lineares envolve articulação intersecretarial pois as áreas adjacentes aos córregos possuem diversos agentes atuando sobre elas, de modo que conciliar e dialogar com diferentes interesses e prioridades é um dos grandes desafios no planejamento e projeto dos parques lineares.

Com dimensões entre $10.000 \mathrm{~m}^{2}$ e $224.000 \mathrm{~m}^{2}$, os parques lineares paulistanos (Fig. 4) tiveram diversas estratégias de implantação, desde aproveitamento das áreas livres públicas junto aos córregos até desapropriação.

Em treze anos, desde a gestação dos parques lineares, houve resultados diversos em termos de aceitação da população. Alguns parques foram apropriados pela população, enquanto outros têm problemas de manutenção, gestão e não consolidaram como espaço público.

Muitos dos parques lineares implantados em áreas públicas não possuem visibilidade, acessibilidade nem apropriação pelos moradores, pois estão situados em remanescentes de loteamentos ou fundos de lotes. O resultado são áreas inóspitas e evitadas por usuários e moradores devido à insegurança do local e à ausência de visibilidade.

A falta de apropriação é aumentada pela carência de políticas municipais de gestão e avaliação pós-implantação. Alguns parques lineares foram inaugurados e um ano depois já não tinham mais os mobiliários, brinquedos, nem mesmo pisos e areias do playground, retirados pela população para serem utilizados em suas residências.

Pela condição de serem abertos, os equipamentos dentro dos parques devem ser resistentes, de baixa manutenção e padronizados, de forma que os recursos de manutenção da SVMA sejam mais bem empregados. Com 116 parques existentes, há apenas três bases de manutenção para atender a todos, e os serviços são realizados parcialmente devido à ausência de material ou de equipe para a execução dos serviços.

O contraste é acentuado quando comparados aos parques de gestão estadual dentro da cidade de São Paulo. A maioria deles tem bases de manutenção em cada parque para atender as ocorrências. A diferença ocorre também na remuneração dos 


\begin{tabular}{|c|c|c|c|c|c|c|}
\hline \multicolumn{7}{|c|}{ PARQUES PROPOSTOS PELO PROGRAMA PARQUES LINEARES } \\
\hline & PARQUE LINEAR & SUBPREFEITURA & ÁREA PLANEJADA & ABERTURA & SITUAÇÃO EM 2019 & ÁREA IMPLANTADA \\
\hline 01 & Água Podre & Butantã & $40.000 \mathrm{~m}^{2}$ & & Não implantado & \\
\hline 02 & Água Vermelha & Itaim Paulista & $50.000 \mathrm{~m}^{2}$ & 2009 & Implantado & 124.000 \\
\hline 03 & Aricanduva Foz & Aricanduva & $50.000 \mathrm{~m}^{2}$ & 2008 & Implantado & 70.000 \\
\hline 04 & Bispo & Casa Verde & $1.000 .000 \mathrm{~m}^{2}$ & & Não implantado & \\
\hline 05 & Cabuçu de baixo & Jaçanã-Tremembé & $40.000 \mathrm{~m}^{2}$ & & Não implantado & \\
\hline 06 & Canivete / Bananal & Brasilândia & $500.000 \mathrm{~m}^{2}$ & 2010 & Imp. Parcialmente & 46.000 \\
\hline 07 & Caulim & Capela do Socorro & $3.000 .000 \mathrm{~m}^{2}$ & 2010 & Imp. Parcialmente & 112.300 \\
\hline 08 & Caxingui & Butantã & $40.000 \mathrm{~m}^{2}$ & & Não implantado & \\
\hline 09 & Cipoaba & São Mateus & $40.000 \mathrm{~m}^{2}$ & & Não implantado & \\
\hline 10 & Cocaia & Capela do Socorro & $700.000 \mathrm{~m}^{2}$ & 2011 & Imp. Parcialmente & 65.000 \\
\hline 11 & Dutra * & Capela do Socorro & $40.000 \mathrm{~m}^{2}$ & 2008 & Implantado & 40.000 \\
\hline 12 & Feitiço da Vila & Campo Limpo & $40.000 \mathrm{~m}^{2}$ & 2015 & Implantado & 38.400 \\
\hline 13 & Fogo & Pirituba & $30.000 \mathrm{~m}^{2}$ & 2008 & Implantado & 39.300 \\
\hline 14 & Freitas & M'boi Mirim & $30.000 \mathrm{~m}^{2}$ & & Não implantado & \\
\hline 15 & Guaratiba & Guaianazes & $30.000 \mathrm{~m}^{2}$ & 2009 & Implantado & 19.000 \\
\hline 16 & Invernada & Santo Amaro & $30.000 \mathrm{~m}^{2}$ & 2012 & Implantado & 6.400 \\
\hline 17 & Ipiranguinha & Aricanduva & $10.000 \mathrm{~m}^{2}$ & 2008 & Implantado & 19.500 \\
\hline 18 & Itaim & Itaim Paulista & $50.000 \mathrm{~m}^{2}$ & 2008 & Implantado & 68.000 \\
\hline 19 & Itapaiúna & Campo Limpo & $40.000 \mathrm{~m}^{2}$ & & Não implantado & \\
\hline 20 & Itararé & Butantã & $40.000 \mathrm{~m}^{2}$ & & Não implantado & \\
\hline 21 & Mongaguá & Erm. Matarazzo & $70.000 \mathrm{~m}^{2}$ & 2011 & Implantado & 48.000 \\
\hline 22 & Nascentes do Aricanduva & Cidade Tiradentes & $250.000 \mathrm{~m}^{2}$ & & Não implantado & \\
\hline 23 & Oratório & Sapopemba & $40.000 \mathrm{~m}^{2}$ & 2013 & Implantado & 28.600 \\
\hline 24 & Parelheiros & Parelheiros & $35.000 \mathrm{~m}^{2}$ & 2007 & Implantado & 25.000 \\
\hline 25 & Perus & Perus & $1.700 .000 \mathrm{~m}^{2}$ & & Não implantado & \\
\hline 26 & Pires-Caboré & Butantã & $40.000 \mathrm{~m}^{2}$ & & Não implantado & \\
\hline 27 & Rapadura & Aricanduva & $30.000 \mathrm{~m}^{2}$ & 2008 & Implantado & 16.500 \\
\hline 28 & Recanto dos Humildes & Perus & $5.000 \mathrm{~m}^{2}$ & & Não implantado & \\
\hline 29 & Rio Verde & Itaquera & $40.000 \mathrm{~m}^{2}$ & 2012 & Implantado & 55.000 \\
\hline 30 & Rodeio * & Cidade Tiradentes & $40.000 \mathrm{~m}^{2}$ & 2008 & Implantado & 613.000 \\
\hline 31 & São José * & Capela do Socorro & $30.000 \mathrm{~m}^{2}$ & 2008 & Implantado & 95.000 \\
\hline 32 & Sapé & Butantã & $30.000 \mathrm{~m}^{2}$ & 2009 & Implantado & 24.800 \\
\hline 33 & Taboão & Aricanduva & $40.000 \mathrm{~m}^{2}$ & & Não implantado & \\
\hline \multicolumn{3}{|c|}{ ÁREA TOTAL } & $8.150 .000 \mathrm{~m}^{2}$ & & & \\
\hline
\end{tabular}

Tabela 1. Os parques com asteriscos não possuem elementos, como a linearidade, integração com entorno e usos cotidianos, que se aproximem do parque linear. Então, dos 20 parques lineares propostos pelo Programa de Parques Lineares, três não podem entrar nesta categoria. Fonte: DEVECCHI, IKEDA e ALEX (2009), com ajustes realizados pelos autores. 


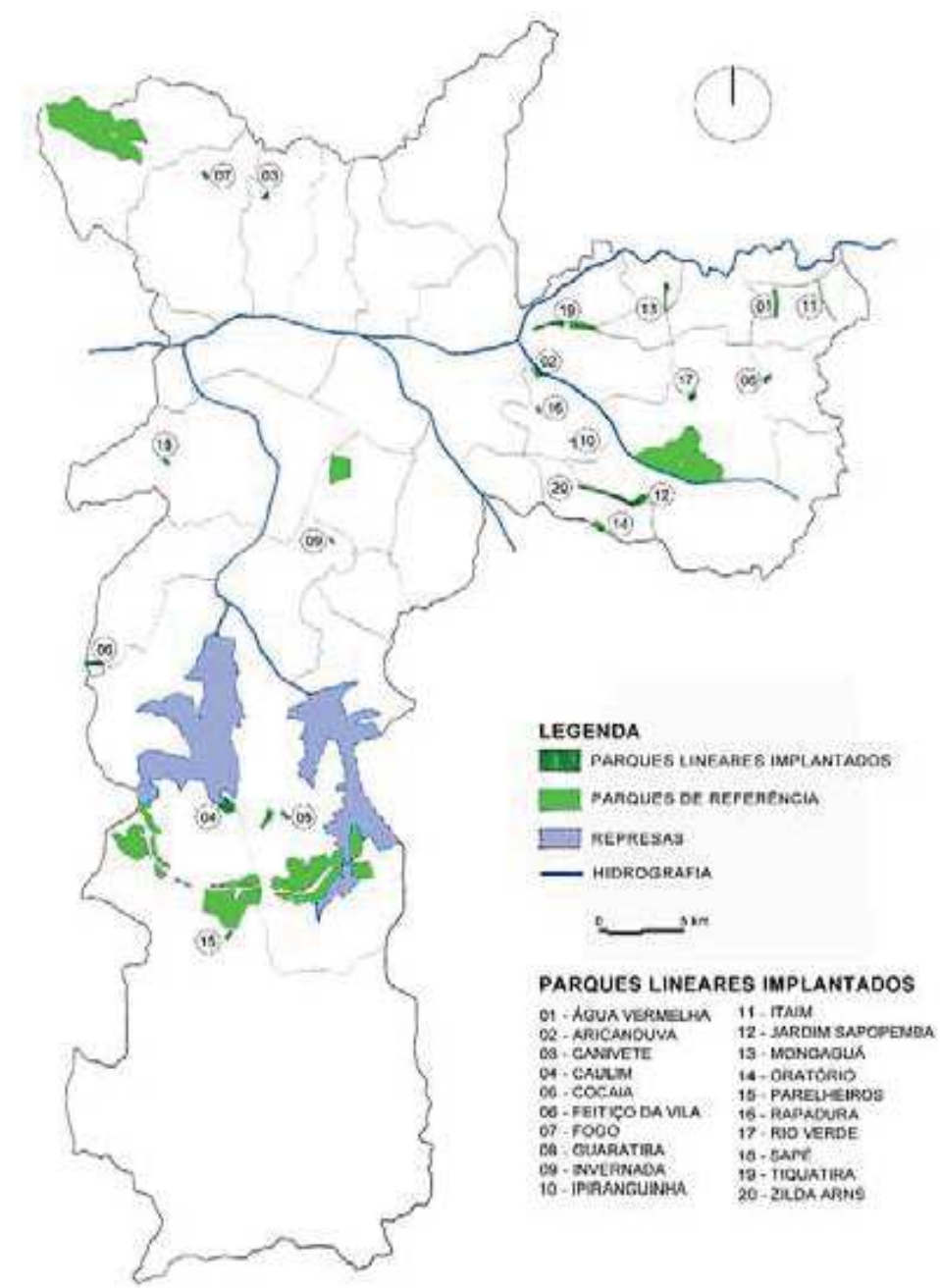

Figura 4 - Parques lineares administrados pela SVMA em 2015. Dois parques lineares foram implantados fora do Programa de Parques Lineares: Zild Arns, implantado pela SABESP e transferido para a SVMA, e o Parque Jardim Sapopemba, implantado durante o Programa 100 Parques. Desenho: Wellington Tohoru Nagano. administradores de parques, uma vez que funções semelhantes têm valores diferentes. Em 2012, o salário do diretor da Divisão Técnica de Administração do Parque Ibirapuera era 40\% inferior ao salário do administrador do Parque Villa-Lobos, de gestão estadual e com funções menos complexas que o parque municipal (BERGAMASCO, 2012). Considerando os administradores dos outros parques da SVMA, a diferença com a contraparte estadual chegava a quase $60 \%$.

Até entre os parques lineares há diferenças na quantidade de funcionários. Em 2012, foi realizado o levantamento das equipes de manejo de alguns parques lineares de São Paulo e posteriormente atualizado em maio de 2016 (Tab. 2).

Nota-se a desigualdade dos números de funcionários de manejo em números relativos e absolutos dos parques selecionados. Analisando-se os dados de 2012, pode ser percebido que o Parque Linear Itaim tem $50 \%$ menos funcionários que o Parque Linear Canivete, apesar de possuir área 50\% maior. Proporcionalmente, o funcionário do Parque Linear Itaim tem mais área para cuidar que o semelhante no Canivete e Guaratiba. O resultado é a ineficiência no serviço de manejo do parque. A situação se agravou em 2016, quando o número de funcionários diminuiu devido ao corte de despesas realizadas pela SVMA.

É importante observar que não está incluída na tabela a quantidade de vigilantes em cada parque. No Parque Linear Guaratiba, por exemplo, em 2012 existiam 14 vigilantes revezando-se dia e noite no local. Somando o número de funcionários administrativos do parque, mais a equipe de manejo e vigilantes, chegase ao número de 25 funcionários dedicados a um único parque, ocasionando somas vultosas no custeio de pessoal. Em novembro de 2016, a maioria dos parques da SVMA estava sem contratos de manejo e vigilância, com risco de vandalismo, resultando em gastos desnecessários para a recuperação dessas áreas verdes. São necessárias novas formas de gestão dos parques (tantos lineares quanto os tradicionais), integradas à comunidade do entorno, agentes públicos e entidades do terceiro setor. 


\begin{tabular}{|c|c|c|c|c|c|}
\hline \multicolumn{6}{|c|}{ FUNCIONÁRIOS DAS EQUIPES DE MANEJO EM ALGUNS PARQUES LINEARES DE SÃO PAULO } \\
\hline PARQUE LINEAR & ÁREA $\left(m^{2}\right)$ & $\begin{array}{c}\text { EQUIPE DE MANEJO } \\
08 / 2012\end{array}$ & FUNC./M² & $\begin{array}{c}\text { EQUIPE DE MANEJO } \\
05 / 2016\end{array}$ & FUNC./M² \\
\hline Canivete & $46.000 \mathrm{~m}^{2}$ & 09 & 5.111 & 05 & 9.200 \\
\hline Guaratiba & $19.000 \mathrm{~m}^{2}$ & 09 & 2.111 & 04 & 4.750 \\
\hline Itaim Paulista & $68.000 \mathrm{~m}^{2}$ & 06 & 11.333 & 04 & 17.000 \\
\hline
\end{tabular}

Tabela 2:

Tabela 2:
Fonte: Levantamento realizado pelos autores junto à SVMA, através de entrevistas com os administradores de parques.

\section{Análise dos Parques Lineares}

Três parques lineares foram analisados, situados em zonas distintas da periferia paulistana: Canivete, Guaratiba e Itaim. Todos eles têm em comum o fato de estarem em locais de moradia de população de baixa renda, que enfrentam problemas como crimes, desemprego, moradias inadequadas, baixa escolaridade e ocupação sobre áreas ambientalmente frágeis (rios e morros). Cada parque linear teve uma estratégia de implantação: o Canivete foi realizado por meio de articulação entre a SVMA, Subprefeitura da Freguesia do Ó e SEHAB na reurbanização da Favela do Canivete; o Guaratiba foi implantado pela SVMA em terreno cedido pela Companhia Paulista de Trens Metropolitanos (CPTM); e o Itaim foi construído em parceria entre SVMA e Subprefeitura do Itaim Paulista sobre áreas públicas existentes e remanescentes de loteamentos ao longo do Córrego Itaim, com o objetivo de evitar a reocupação de suas margens. Cada forma de planejamento, projeto e gestão desses parques influenciou suas apropriações, gerando desde uma população local que reconhece os benefícios do novo espaço público (Canivete) até uma comunidade que não se apropria do lugar (Itaim).

\section{Parque Linear canivete}

O Parque Linear Canivete foi implantado pela Subprefeitura da Freguesia do Ó/Brasilândia, em 2010. Previsto no Plano Diretor de 2002 e criado pelo Decreto 49.607/2008, é um dos núcleos previstos do Parque Linear Bananal-Canivete, previsto para ser a área de transição entre a urbanização da Subprefeitura e a Serra da Cantareira. Antes da implantação do parque linear, o local era ocupado por favelas e sem nenhuma infraestrutura (Fig. 5).

O parque foi constituído de forma articulada com outras secretarias; à Subprefeitura da Freguesia do Ó coube a remoção das ocupações e canalização do Córrego Canivete. A SVMA elaborou o projeto e repassou as verbas para à SEHAB, responsável pela licitação, acompanhamento das obras, provisão das famílias removidas e construção do tronco coletor de esgoto na Rua Hugo Ítalo Merigo. Apesar do tronco coletor, o esgoto continua a ser jogado no Córrego Canivete, pois há despejos de detritos nas escadas hidráulicas que vão em direção ao curso d'água.

O Parque Linear Canivete é composto por calçadas largas, arborizadas, com os equipamentos de maior uso junto a elas, enquanto que usos ocasionais foram dispostos na outra margem do córrego, mas sem prejudicar a visibilidade deles perante a Rua Hugo Ítalo Merigo, que circunda o parque (Fig. 6). Um dos principais elementos da requalificação urbanística que o parque linear trouxe foi o desenho dessa rua, que ganhou infraestrutura básica e pavimentação (Fig. 7), e o desenho do Córrego Canivete (Fig. 8), que teve suas margens canalizadas por gabiões, cuja rugosidade ameniza a velocidade da água em dias de chuva.

Para as obras do parque, a empresa selecionada para a construção contratou moradores do próprio bairro que, após o término 


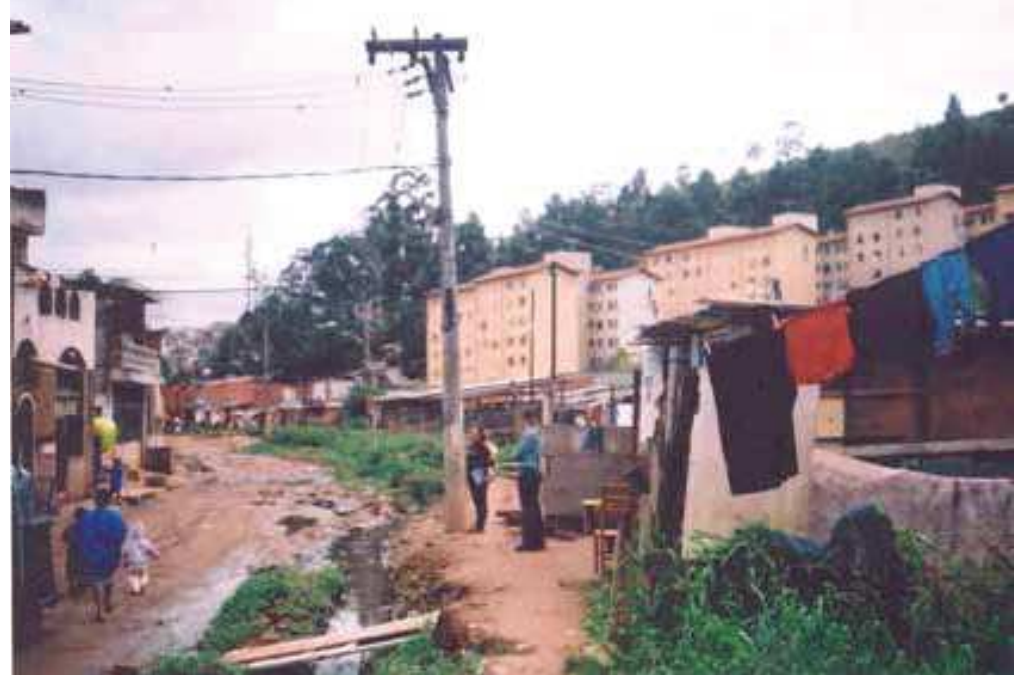

Figura 5 - Rua Hugo Ítalo Merigo antes da implantação do Parque Linear Canivete: ausência de calçadas, esgoto a céu aberto, pinguela, rua pre-

Foto: SVMA, 2006

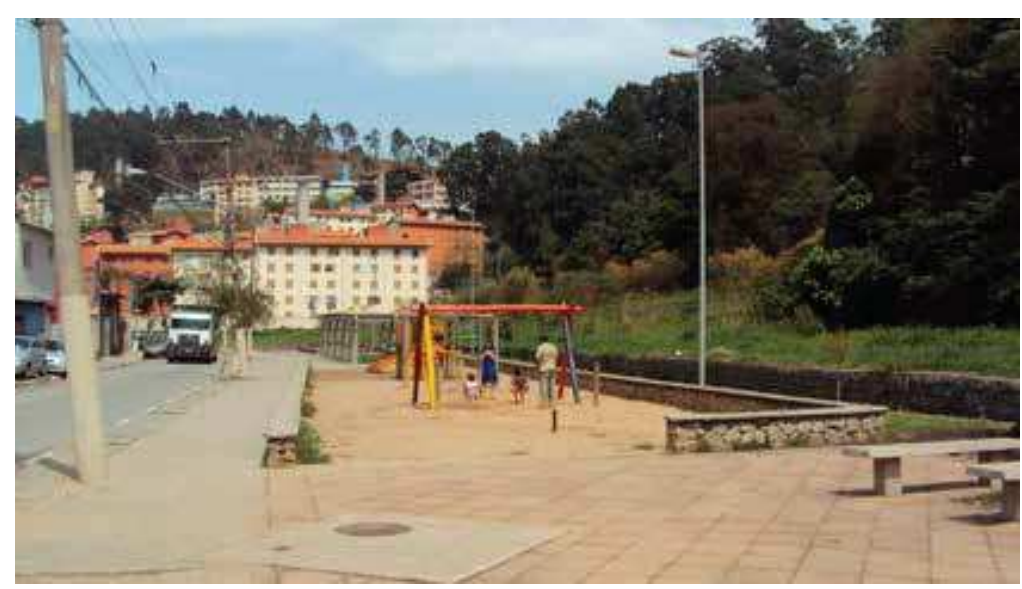

Figura 7 - Rua Hugo Ítalo Merigo, após a implantação do parque linear: rua asfaltada, calçada larga, equipamentos para lazer e fruição e córrego

canalizado por gabióes.

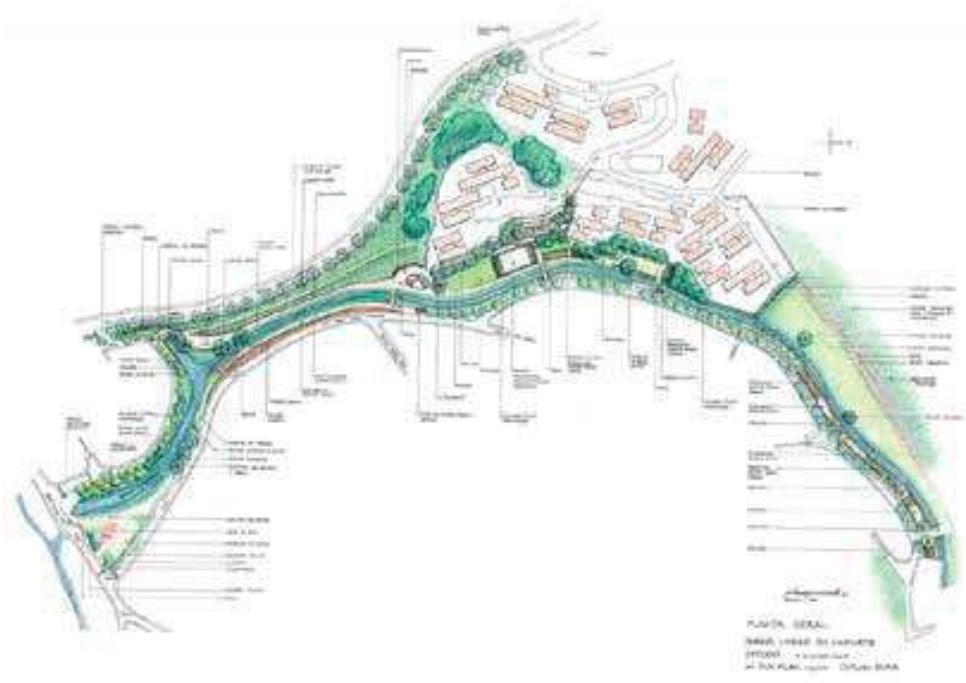

Figura 6 - Parque Linear Canivete.

Desenho e Projeto: Sun Alex, SVMA, 2008

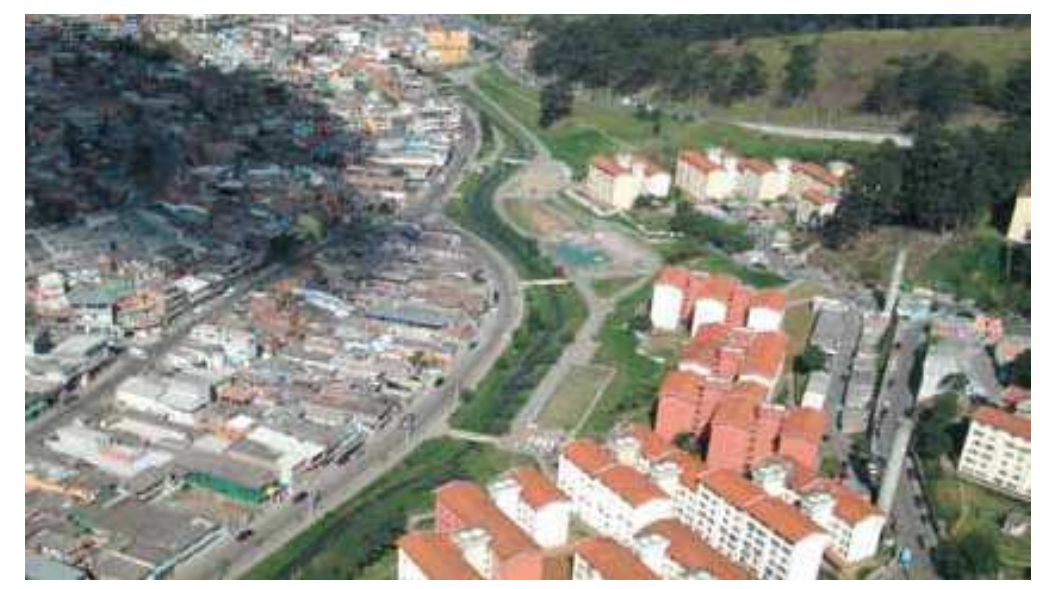

Figura 8 - Parque Linear Canivete, com o córrego homônimo localizado

Foto: Wellington Tohoru Nagano, 2014 
da obra, continuaram trabalhando como ajudantes, jardineiros e encarregados da empresa de manejo. Além de promover empregos locais, essa iniciativa - realizada de forma empírica - transformou esses funcionários em guardiões do parque e ajudou a estabelecer redes de vínculos informais entre o Poder Público e os moradores. Reconhecidos pela população do entorno, eles têm mais autonomia para cuidar do espaço público do que os vigilantes, que são geralmente vistos com ressalvas pelos moradores como autoridades da polícia, sendo que a função deles é apenas proteger o patrimônio público e relatar ocorrências dentro do parque, sem atribuições para atuação.

Anualmente, é realizada ali a Feira de Saúde Sustentável, na qual órgãos públicos e organizações não governamentais prestam serviços de utilidade pública para a população. No cotidiano, as principais atividades praticadas no parque são caminhadas (individuais ou por grupos formados por postos de saúde, fig. 9), esportes, pequenas reuniões, uso do playground ou simplesmente como área de estar e de passagem.

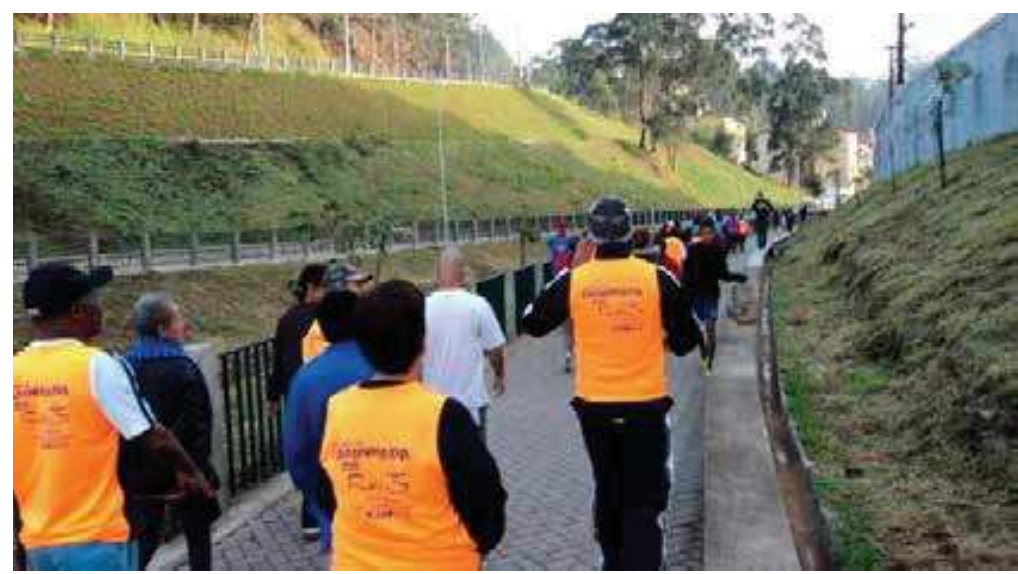

Figura 9 - Realização de caminhada no parque. Foto: Ana Beatriz Silva Lima, 2011.
Em 2014, houve a falência da empresa responsável pela vigilância de todos os parques municipais e, no caso do Parque Linear Canivete, o contrato de manejo havia expirado meses antes. Apesar da ausência dos funcionários, os equipamentos - de modo geral - ficaram intactos, sendo o único problema nítido registrado a vegetação alta. Isso mostra como o espaço público apresentou resiliência diante da precariedade da SVMA em ter plano de contingência para quebras de contratos.

O Parque Linear Canivete promoveu a mudança das dinâmicas urbanas do Jardim Damasceno. A Rua Hugo Ítalo Merigo foi valorizada com a implantação do parque e as diversas atividades realizadas depois de aberto, em 2010, mostram como o Estado - através de diversos agentes, muitos, às vezes por iniciativas próprias e desarticuladas - consegue criar a valorização da região e aumentar a presença da esfera pública. Em uma região carente de espaços públicos, a implantação do Parque Linear Canivete trouxe novas dinâmicas urbanas (a realização de eventos, mobilidade, tratamento do córrego e ponto de identidade do bairro) e aumento do senso de cidadania dos moradores do entorno. O parque se aproximou das diretrizes estabelecidas pelo PDE de 2002.

\section{Parque linear Guaratiba - Núcleo Estação}

O Parque Linear Guaratiba (Fig. 10) está inserido próximo ao centro da Subprefeitura de Guaianases, perto da delegacia, do CEU Jambeiro, do centro comercial e da estação Guaianases da CPTM. Com $19.000 \mathrm{~m}^{2}$ e sem decreto de criação, o parque implantado corresponde a uma fração de um parque linear maior, com 4 km, indo desde a nascente do Córrego Guaratiba, na Subprefeitura Cidade Tiradentes, até o encontro com o Rio Itaquera.

O terreno ocupado pelo parque pertence teoricamente à CPTM, que o repassou à municipalidade, a título precário, sem documento fundiário formal de transferência. Com a situação ambígua sobre a titularidade do terreno, a CPTM retomou parte da área cedida para a construção de um pátio de trens (Fig. 11). O parque difere-se dos outros lineares por ter cercamento, por ser 


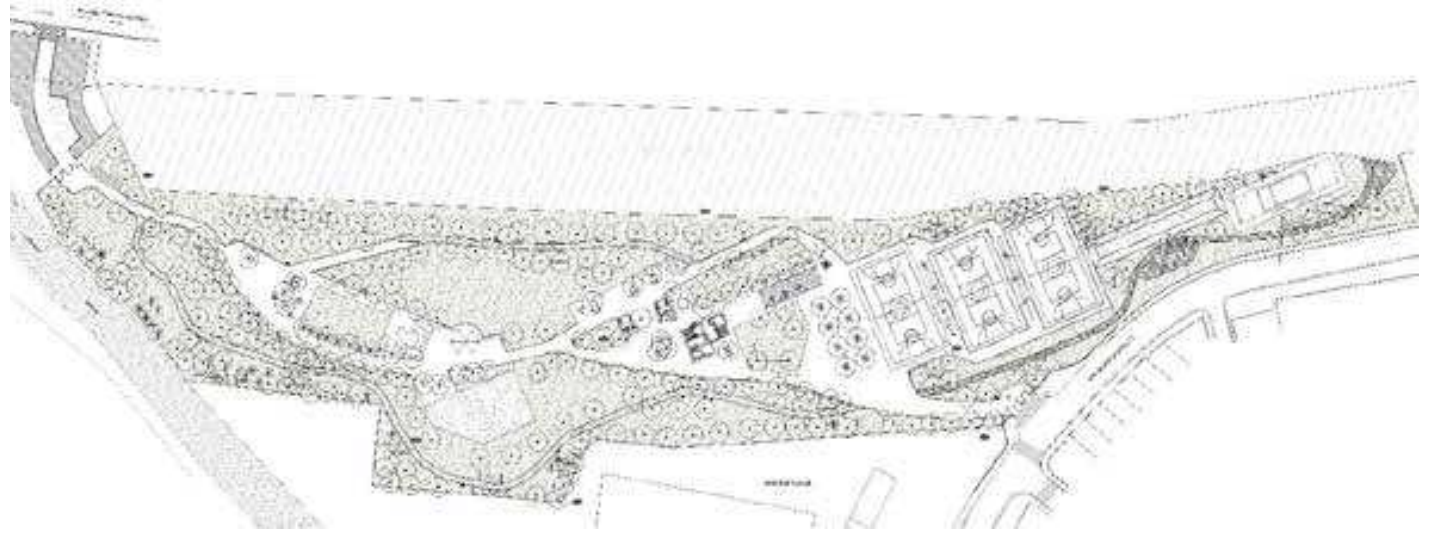

Figura 10 - Parque Linear Guaratiba.

Toho Nagano, a par-

tir de planta fornecida pela SVMA, 2012.

110

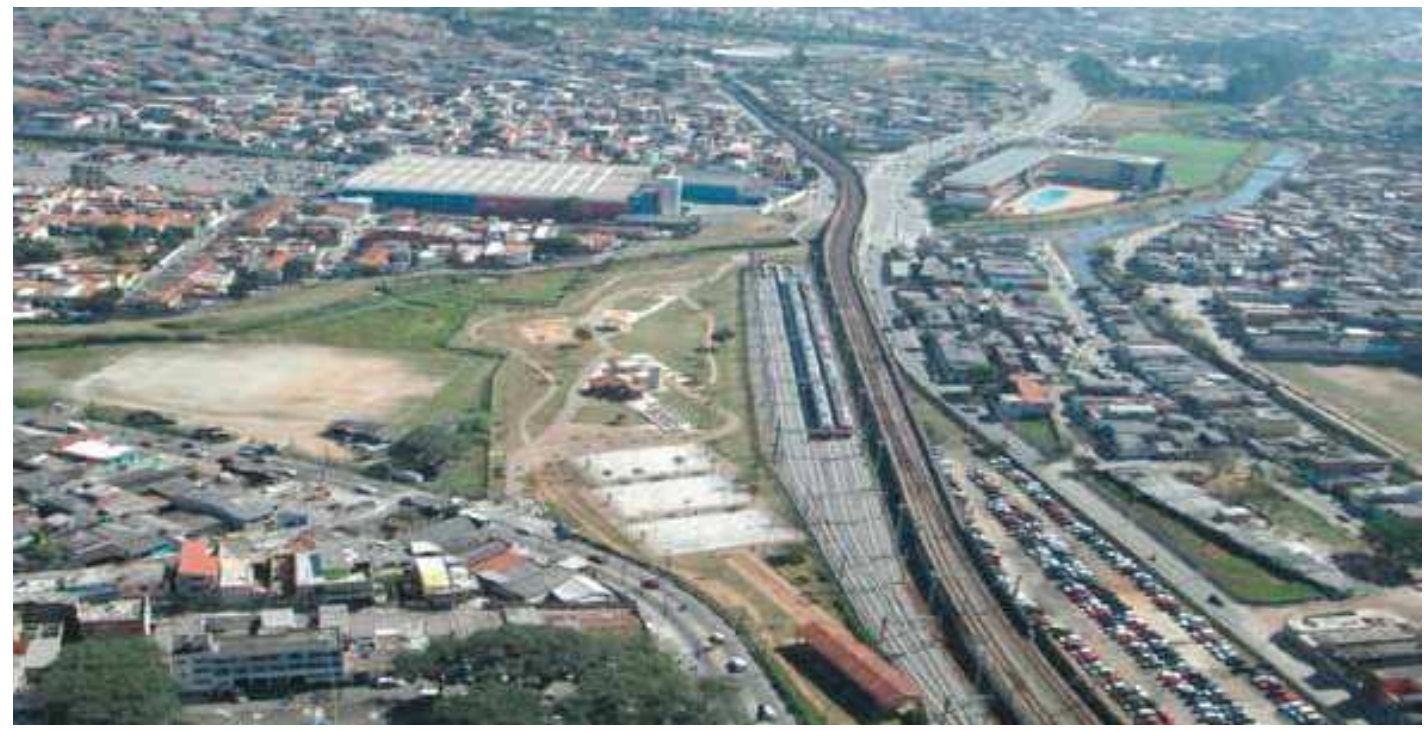

Figura 11- Parque Linear Guaratiba - Núcleo Estação. À esquerda, encontra-se o terreno do campo de futebol que será incorporado ao parque e, à direita, está o pátio de tren que usou parte do parque implantado. 
um dos poucos a possuir administração exclusiva no local, além de ser um dos que têm menor contato com o rio.

É caracterizado pela quantidade de quadras poliesportivas e por ser passagem entre o centro de Guaianases e o CEU Jambeiro. Em 2012, foi feita a readequação do parque, com a eliminação de caminhos desnecessários, construção de sanitários públicos quiosque, playground, equipamentos de ginástica e novas áreas de estar.

Foi um dos parques mais afetados pela crise de vigilância e manejo em 2014. O edifício-sede e sanitários foram depredados, peças metálicas e até mesmo os cabos dos postes foram furtados. Sem a presença de vigilantes para fechar o parque à noite, tornouse local inóspito para travessias e o parque, que antes era bem movimentado e com diversos usos durante o dia, tornou-se um lugar inseguro e evitado pelos moradores. Mesmo localizado no centro do distrito de Guaianases, com delegacia quase em frente ao parque, base da Guarda Civil Municipal próxima ao CEU Jambeiro e presença de seguranças da CPTM no pátio de trens, não foi possível evitar depredações. Fica, assim, evidente como o mesmo Estado não consegue articular para que agentes externos colaborem em situação adversas.

A geometria do parque também não favorece a relação com o entorno, pois o desenho não privilegia o contato com a rua, a calçada junto ao parque é estreita e carece de acessibilidade existem poucas edificações voltadas para o parque e há barreiras físicas (pátio, viaduto de trem e campo de futebol) que aumentam a percepção de isolamento do parque. Apesar da visibilidade para quem está no trem ou no carro, a vista é impossível para quem está andando próximo ao parque. Jacobs (2011) já demonstrava a importância do entorno (edificações, usos e ruas) na vitalidade de um parque. No caso do Parque Linear Guaratiba, mesmo estando em área central, de ser movimentado e de ter diversos equipamentos públicos ao redor, o parque não conseguiu se manter de forma autônoma.

\section{Parque Linear Itaim}

O Parque Linear Itaim (Fig. 12) está localizado na Subprefeitura do Itaim Paulista e foi um dos primeiros inaugurados em 2008. Faz parte do segundo momento de planejamento de parques lineares, sendo repassado pela subprefeitura à SVMA.

A origem do Parque Linear Itaim remonta da iniciativa da subprefeitura homônima de retirar as moradias de alto risco junto ao Córrego Itaim e recuperar ambientalmente o curso d'água, melhorando a drenagem próxima às margens.

Coube à SVMA o projeto e o repasse de verbas para a subprefeitura, enquanto esta última ficou responsável pela licitação e pelo acompanhamento da obra. O parque foi implantado em áreas públicas (na maioria fundos de lotes), decorrentes do parcelamento fundiário, sem a realização de nenhuma desapropriação.

Com $68.000 \mathrm{~m}^{2}$, o parque possui vários núcleos que representam diversos contextos no qual está inserido. Os trechos mais apropriados do parque são aqueles onde há uma estrutura espacial bem definida, com limite claro do espaço público através do sistema viário, visibilidade para quem está dentro ou fora do parque, e com entorno diversificado (Fig. 13). As áreas remanescentes de loteamento de fundos de lotes não foram apropriadas, tornando-se, assim, locais inseguros, depósitos de lixo e evitados pelos usuários e moradores do entorno (Fig. 14).

O entorno do Parque Linear Itaim é composto em sua maioria por ocupações irregulares. Em alguns trechos, essas ocupações estão em conflito com o parque linear, pois a ausência de planta fundiária com área e limites torna difícil a análise se a área de litígio é de propriedade da municipalidade ou não.

O impacto urbanístico e paisagístico do Parque Linear Itaim na região foi parcial, pois a questão das ocupações precárias não foi resolvida, o Córrego Itaim continua com pontos de enchentes, espaços residuais tornaram-se locais inóspitos, e a descontinuidade administrativa continua dificultando a implementação de ações 


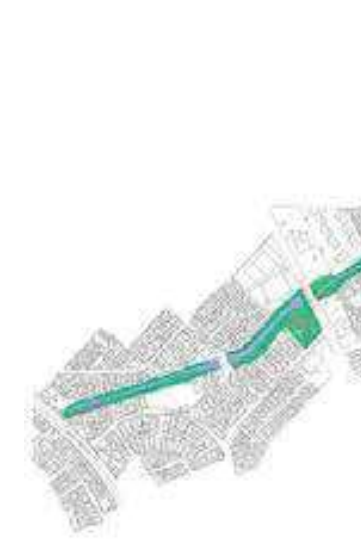

de longo prazo, capazes de buscar a aproximação do parque pela população.

\section{Resultados DA EXPERIÊNCIA}

O aumento dos parques lineares proporcionou novos espaços públicos em áreas periféricas, além de conter ocupações em áreas ambientalmente frágeis. Entretanto, muitos foram criados em áreas de propriedade pública ou residuais de urbanização já existentes, sem aumentar a cobertura de áreas verdes e permeabilidade. Poucos tiveram remoção de moradias irregulares e trouxeram requalificação urbanística para a região.
Figura 12 - Implantação do Parque Linear Itaim. Desenho: Wellington Tohoru Nagano.
Ao invés de promover o encontro de pessoas, o convívio social, de ser acesso e lugar de convergência, diversos parques lineares permanecem isolados e sem apropriação pelos cidadãos. O esvaziamento do espaço público pode ocasionar a individualização, justamente onde deveria ocorrer a cidadania e a tolerância (BAUMAN, 2001).

Os parques lineares paulistanos demonstram a assimetria dos investimentos públicos nos espaços livres centrais e periféricos. Em áreas centrais, os espaços livres têm mais visibilidade pela mídia, pelas elites e por usuários que utilizam frequentemente esses locais, exigindo do poder público a manutenção constante, gerando o interesse político em manter conservados esses espaços. 


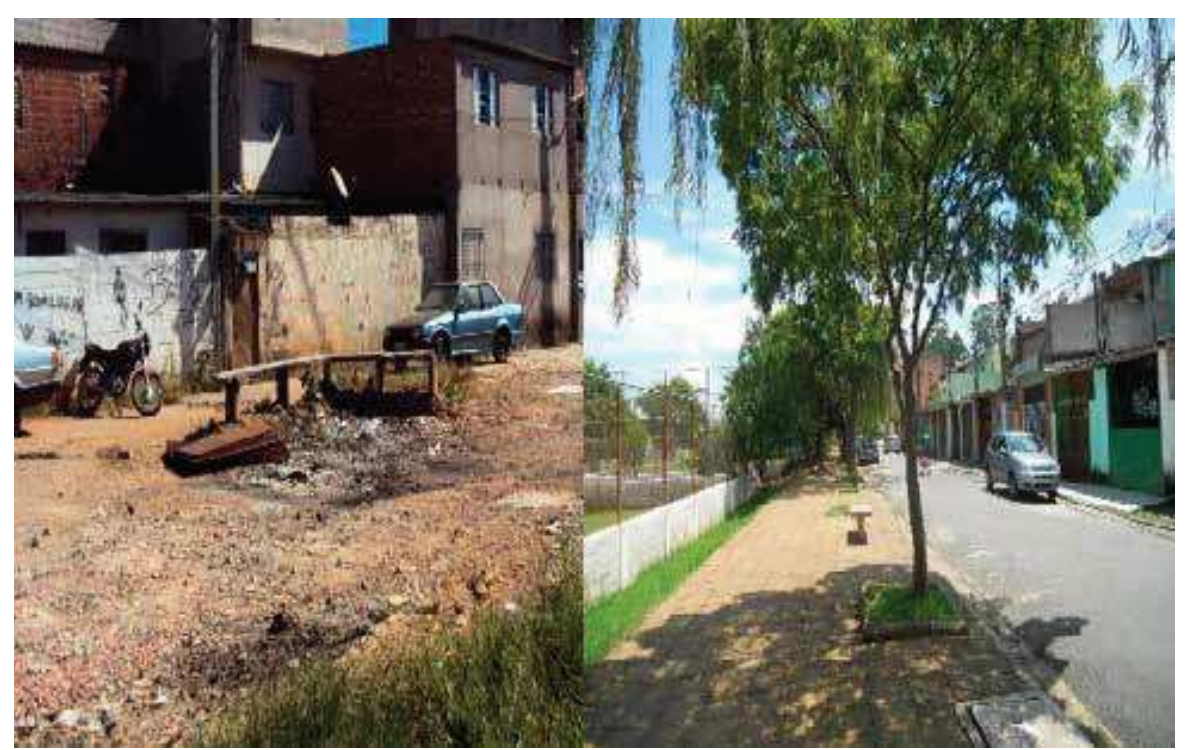

Figura 13 - Trecho do Parque Linear Itaim, com hierarquia de

funções: habitação, rua como divisor do espaço público e do

espaço privado, arborização, calçada larga, equipamento e

Córrego Itaim (não mostrado na foto). Foto: SVMA, 2012.

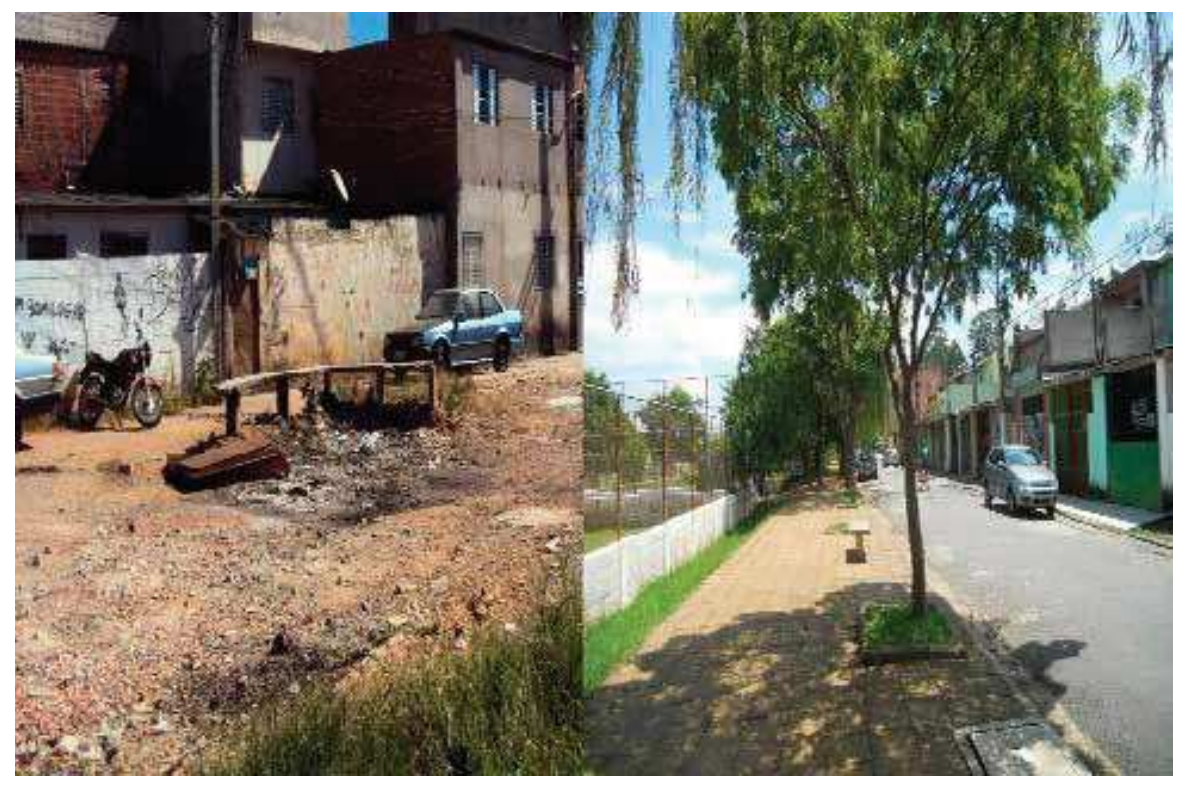

Figura 13 - Trecho do Parque Linear Itaim, com hierarquia de funções: habitação, rua como divisor do espaço público e do espaço privado, arborização, calçada larga, equipamento e o Córrego Itaim (não mostrado na foto). Foto: SVMA, 2012. 
Os três parques lineares aqui comentados não podem ser considerados como parâmetros para o restante, pois cada um tem sua particularidade no planejamento, projeto, obras e gestão. Eles demonstram a complexidade da gestão dos espaços públicos diante das limitações orçamentárias, da estrutura arcaica da administração pública, da ausência de continuidade de políticas públicas e das dificuldades sociais. Esses percalços na implantação dos parques lineares impuseram intervenções tão tímidas que não foram suficientes de qualificá-los como espaços públicos, com pouca apropriação pelos moradores e usuários, além de não conseguirem desempenhar um papel de importância da esfera pública dentro do sistema de espaços livres.

A gestão dos parques lineares deve ter a mesma importância que o planejamento e projeto, pois é a única dentre os três que atua no cotidiano local e a que tem maior importância na apropriação do espaço público, através de políticas públicas, manutenção e reforma, avaliação pós-implantação, aproximação entre gestor, usuários e moradores, e como mediador dos conflitos entre pessoas. O Estado, como gestor do espaço público, deve garantir a mediação por meio da proteção aos direitos civis, da imparcialidade e da criação de espaços públicos acessíveis e flexíveis. Em São Paulo, onde a população mais pobre ocupou rios e morros de forma anárquica, o parque linear é a oportunidade de reverter esse tipo de ocupação e aumentar a apropriação dos espaços públicos na periferia, conciliando a ocupação com a natureza e aumentando a cidadania dos moradores e usuários.

\section{REFERÊNCIAS BibLIOGRÁFICAS}

BAUMAN, Zygmunt. Modernidade líquida. Rio de Janeiro: Editora Zahar, 2001

BERGAMASCO, Daniel. Os prefeitos dos parques paulistanos. Revista Veja SP. Disponível em https://vejasp.abril.com.br/cidades/administracao-parques-paulistanos/. Acesso em 18 de setembro de 2016.

BRASIL. Lei 6.766, de 19 de dezembro de 1979. Dispõe sobre o Parcelamento do Solo Urbano e dá outras Providências. Diário Oficial da União, Brasília, DF, 20 de dezembro de 1979. Disponível em: http://www.planalto.gov.br/ccivil_03/leis/l6766.htm. Acesso em: 10 de agosto
de 2016 .

BRASIL. Lei 7.803, de 18 de julho de 1989. Altera a redação da Lei $n^{\circ} 4.771$, de 15 de setembro de 1965, e revoga as Leis $n^{\circ} \mathrm{s} 6.535$, de 15 de junho de 1978, e 7.511, de 7 de julho de 1986 . Diário Oficial da União. Brasília, DF, 20 de julho de 1989. Disponivel em: https://www.planalto.gov.br/ccivil_03/LEIS/L7803.htm\#art4. Acesso em: 18 de junho de 2017.

BRASIL. Resolução CONAMA n 369 , de 28 de março de 2006. Dispõe sobre os casos excepcionais, de utilidade pública, interesse social ou baixo impacto ambiental, que possibilitam a intervenção ou supressão de vegetação em Área de Preservação Permanente -APP. Diário Oficial da União, Brasília, DF, 29 de março de 2006. Disponível em: http://www.mma.gov.br/
port/conama/legiabre.cfm?codlegi=489. Acesso em: 23 de maio de 2016 .

DEVECCHI, Alejandra M. IKEDA, Rosélia M. ALEX, Sun. Os parques lineares como estratégia de recuperação ambiental na cidade de São Paulo. São Paulo: Secretaria do Verde e do Meio Ambiente, 2009.

FRIEDRICH, Daniela. O parque linear como instrumento de planejamento e gestão das áreas de fundo de vale urbanos. 2007. 273p. Dissertação (Mestrado em Arquitetura e Urbanismo) Faculdade de Arquitetura, Universidade Federal do Rio Grande do Sul, Porto Alegre, 2007. Editora, 2011

LYNCH, Kevin A. Good city form. Boston: The MIT Press, 1981.

PANZINI, Franco. Projetar a natureza: arquitetura da paisagem e dos jardins desde as origens até a época contemporânea. São Paulo: Editora SENAC, 2013.

QUEIROGA, Eugênio F. Dimensões públicas do espaço contemporâneo: resistências e transformações de territórios, paisagens e lugares urbanos brasileiros. 2012. 284p. Tese (Livre Docência em Arquitetura e Urbanismo) - Faculdade de Arquitetura e Urbanismo, Universidade de São Paulo, São Paulo, 2012

SÃO PAULO (Município), Lei 13.430, de 13 de setembro de 2002. Plano Diretor Estratégico. Diário Oficial do Município de São Paulo. São Paulo, SP, 14 de setembro de 2002. p. 1.

THE EMERALD NECKLACE CONSERVANCY. Emerald Necklace Map. Disponível em: https:// www.emeraldnecklace.org/park-overview/emerald-necklace-map/ Acesso em: 18 de dezembro de 2016. 
Wellington Tohoru Nagano

Unversidade São Judas Tadeu, Faculdade de Letras, Artes, Comunicação

e Ciências da Educação

Rua Taquari, 546, Mooca - São Paulo, SP

CV: http://lattes.cnpq.br/8773973966127898

Orcid: https://orcid.org/0000-0001-9408-0344

E-mail: naganowtn@yahoo.com.br

Fábio Mariz Gonçalves

Universidade de São Paulo, Faculdade de Arquitetura e Urbanismo

Rua do Lago, 876 - Butantã, São Paulo - SP

CV: http://lattes.cnpq.br/7510626259603659

Orcid: https://orcid.org/0000-0002-8419-0686

E-mail: fabiomgoncalves@usp.br

Nota do Editor

Revisão de texto: Ana Drummond Guerra

Submetido em: 29/11/2016 